Lucina, Arca, Ostrea, Purpura, Tritonium, Trochts, \&c.), all of which are at present living in the neighbouring sea. (2) Sambaquis, consisting almost exclusively of a small bivalve shell, the "Birbigãs" of the Brazilians (Venus flexuosa?), exceedingly common in shallow bays or salt-water lagoas, the bottom of which is of mixed mud and sand. (3) Sambaquis, consisting cxclusively of a species of Corbula, which I have not yet seen in a living state; all the Brazilians aiso, whom $I$ asked, and who are perfectly acquainted with any edible animal of their marine fauna, are unanimous in affirming that this shell does not live now on our coast. From one of these Corbula-Sambaquis I obtained a specimen of a small Melampus, which I have found living near the mouth of some rivulets, where fresh and salt water are mingling in ever-varying proportions. When the lowlands of the Lower Itajahy and some of its tributaries were as yet beneath the level of the sea, they would have formed a large estuary, and here probably the Corbulæ lived. The fragments of human skulls which we found in one of these Corbula-Sambaquis were of truly astonishing thickness, whereas those I have seen from other Sambaquis are hardiy thicker than our own, A mong the tools which are to be found in the Sambaquis, stoneaxes are by far the most frequent. But as $M$. Wiener will probably soon publish a full account of his researches, I will now no longer dwell on this subject.

Some time ago I sent to Germany for publication a note on the relation between our Imbauba trees (Cecropia) and the ants which inhabit their hollow stem. As there may be some delay in publishing, I will give you a short abstract. Mr. Belt has already stated that the ants farm scale-insects in the cells of the Imbauba stem, and he believes that their presence must be beneficial. This is no doubt the case ; for they protect the young leaves against the leaf-cutting ants (Oecodoma). Now there is a wonderful contrivance by which, as in the case of the "bull's-horn acacia," the attendance of the ants at the right time and place is secured. At the base of each petiole there is a large flat cushion, consisting of most densely-crowded hairs, and within this cushion a large number of small white pear-like or club-shaped bodies (specimens inclosed) are successively developed, which, when ripe, emerge at the surface of the cushion, like asparagus on a bed, and are then greedily gathered by the ants and carried away to the nest. The object of the dense hair-cushion appears to be (I) to secure to the young club-shaped bodies the moisture necesary for their development; and (2) to prevent the ants from gathering the unripe bodies. In most cases it is by honeysecreting glands that the protecting ants ate attracted; now Mr Belt observed ("Nicaragua," p. 225) that the honey-glands on the calyx and young leaves of a Passion-flower were less attractive to the ants than were the scale-insects living on the stems; this would most likely be the case with the Imbauba, and it is probable that the use of the little pear-shaped bodies is to form an attraction stronger than that of the scale-insects, and thus to secure the attendance of the protective ants on the young leaves. As far as I could make out, the club-shaped bodies consist mainly of an albuminous substance. The ant colonies are founded by fertilised females, which may be found frequently in the cells of young Imbauba plants. Each internode has on the outside, near its upper end, a small pit where the wall of the cell is much thinner than anywhere else, and where the female makes a hole by which she enters. Soon after this the hole is completely shut again by a luxuriant excrescence from its margins, and so it remains until about a dozen workers have developed from the eggs of the female, when the hole is opened anew from within by these workers. It would appear that the female ants, living in cells closed all amound, must be protected against any enemy ; but notwithstanding a rather large number of them are devoured by the grub of a parasitic wasp belonging to the Chalcididæ; Mr. Westwood has observed that the pupæ of the Chalcididæ exhibit a much nearer approach to the obtected pupæ of the Lepidoptera than is made by any other Hymenoptera " ("Introd. to the Modern Classif, of Insects," Part XI., p. I62). Now the pupa of the parasite of the Imbauba ant is suspended on the wall of the cell by its pos. terior extremity just like the chrysalis of a butterfly.

I hope you will have received a paper on $\mathbb{E l e a}$, a curious Decapod inhabiting the mountain rivulets of our Serra do Mar. Lately I obtained a large number of specimens of this Eglea, and among them a female with eggs in an advanced state of development. Thus I was enabled to satisfy myself that, like so many fresh-water and terrestrial animals, the marine allies of which undergo a transformation, our Æglea does not experience any metamorphosis.

Itajahy, St. Catharina, Brazil, Dec. 25, 1875

\section{Prof. Tyndall on Germs}

YOuR able correspondent "Inquirer" would hardly blame Horatius for taking his enemies one at a time. May I not, then, claim his indulgence for following, in an extremely humble way, the example of the gallant Roman? He may accept my assurance that during the last five months I have found Dr. Bastian quite enough for me.

Moreover, I do not think it likely that Dr. Sanderson and myself will ever cross swords upon this question. Onr relation, I am happy to think, will be one of co-operation, not of antagonism. The experiments on pure infusions, not those on mixtures of solids and liquids, to which "Inquirer" directs my attention (NATURE, vol. vii., p. I8o), are, in my opinion, too scanty, and too little in harmony with each other, to bear an inference of any weight. To Dr. Sanderson I prefer leaving the repetition of then, with the full confidence that the ability and candour for which he is so distinguished will lead him to a right result.

In repeating these experiments, it wotid, I think, be well to bear in mind the remarks of Dr. Ruberts (NATURE, vol. vii., p. 302), however unimportant they may seem to Dr. Bastian. I would also suggest the substitution, in boiling, of an oil-bath for the Bunsen burner, and, in sealing, the abandonment of the blow-pipe and the use of the simple spirit-lamp flame.

Experiments on milk and pounded cheese are, it may be observed, at present beside the mark. They shall be subjected in due time to the scrutiny already bestowed upon really liquid infusions. It ought not to be forgotten that the jungle we have entered has been growing umbriferously for the last six years, and it is only bit by bit that the sunlight can be let in upon it.

"Inquirer" may count on my sympathetic readiness to minister, however humbly, to the delight he takes in following " every in. vestigation which tends to the development of science." If he cares to see my infusions, it will give me great pleasure to show them to him. Condensed abstracts only of my investigation have been laid before the Royal Society and the Koyal Institution ; a fuller account of it will follow by and by. Meanwhile, I hope "Inquirer" will accept the assurance that I have been strict-I might say abject-ia my adherence to the conditions prescribed by Dr. Bastian in his books.

Heathfield, Feb. $\mathbf{r}_{3}$

[The following letter has been sert us for publication by Prof. Tyrdall.-ED.]

Permettez-MoI de vous dire combien je suis charmé que yous apportiez dans la question de la génération spontanée la grande autorité de votre esprit philosophique et de votre rigeu expérimentale. C'est tout à la fois un honneur pour mes re. cherches et une vive satisfaction personelle que les concinsions auxquelles vous êtes arrivé s'accordent si bien avec celles de mes propres travaux, malgré la différence des méthodes que notis avons suivies. Le tour piquant que vous avez su donner à vos expériences les fera pénétrer plus avant que les miennes dans l'esprit de tout lecteur que n'égarent pas les idées à priori.

Dans le numéro du 5 février courant du British Medical Fournal le docteur Bastian ascepte sans réserve l'exactitude de toutes les expériences de mon mémoire de 1862 (Annales de Physique et de Chimie).

Il accepte également, sans nul doute, les resultats de celles que j'ai publiés en 1863 et en 1872 sur le sang, sur l'urine, sur le jus intérieur des grains de raisin, exposés, dans l'état même où la vie a formé ces liquides complexes, au contact de l'air pur, 